\title{
Asian Economic Dynamics and Power Shifts
}

\author{
Juhi Shah \\ Pandit Deendayal Petroleum University, Raisan, India
}

Copyright $\bigcirc 2019$ by authors, all rights reserved. Authors agree that this article remains permanently open access under the terms of the Creative Commons Attribution License 4.0 International License

\begin{abstract}
As we can see over the last few years, Asia has the fastest growing economies. There is a huge possibility of creation of a new international world system which is going to be led by either the BRICS countries, which has 4 Asian countries of the total 5 members. With the increased economic powers of the Asian countries, many economists worldwide have forecasted that the countries like China, India, Japan, Russia, UAE, South Korea and many others are going to surpass the American or the western system that is followed today. The world is on the verge of seeing a shift in the economic powers. The economies of the Asian countries are by their sheer size becoming economic giants. The countries have experienced a rapid growth in their economies since the 1960s. East Asian countries grew faster than the rest of the world for four key reasons: they have substantial potential for catching up; their geographical and structural characteristics by-and-large favourable; demographic changes following World War II; and their economic policies and strategies. Looking into all these perspectives, the paper will focus on, how the Asian countries are currently fast developing, their position at the global level and how they will determine the future course of world economy Vis-à-vis the west, and power shift at the global level.
\end{abstract}

Keywords Economic Growth, Foreign Policy, Trade, Export \& Import, GDP, Economic Power

\section{Literature Review}

\subsection{The Role of China in Asia's Evolution as Global Economic Prominence by Dilip K Das}

This research article is intended to show how China's rapid growth was instrumental in combining Asian economies with each other and mutually supporting rise of an Asian dynamic. It demonstrates the complete structural change that the Chinese and Asian economies underwent over the last three decades. In a short span of three decades Chinese economy made a sizeable regional and global position for itself. China's whirling growth became instrumental in integrating the real economies in the region. China and neighbouring Asian economies influenced and shaped each other's economic evolution. China influences both regional and global economies as a large saving and high-investing economy. China has emerged as an increased source of foreign direct investor which is bias on Asian basis. China's rise to the status of the second largest global economy, the largest exporter, the second largest importer and the hub of regional production networks has had meaningful ramifications for the Asian economy.

\subsection{India: a Rising Power or a Mere Revolution of Rising Expectations by Jon Dorschner and Aseema Sinha}

This research article discusses the challenges and potential of India in becoming a great power. For India to become a superpower or great power there are numerous challenges domestically as well as internationally that it has to overcome. The initial section of the paper says that India has to cope with the transformation of international system in favour of China as well as project its aspirations of becoming a global power through its foreign policy and diplomatic relations with other countries. According to the authors, India has changed drastically in terms of global activism and strengthening economy. The path for becoming a major power needs to be paved by India and should include more than just good intentions. It should be accompanied by political leadership and powerful diplomatic ties. India can transform from its traditional emphasis on self-reliance and autonomy into real power that is sustainable at the global level. The article concludes that India as a superpower might not be a reality but actually expectation of other countries due to its constant growth and diplomatic ties.

\subsection{Reflections of Wallerstein: the Modern World System, Four Decades on by Chamsy el-Ojeili}

In this research article the author analyses the work of Immanuel Wallerstein-The modern world system after four decades of his publication to examine its relevance in today's time. It begins with recounting the key conceptual and historical claims of a global world system and 
considers broader aspects of economics, culture and politics. It analyses in detail the geo-culture, the inter-state system and the international division of labour. The article theorizes the world system, its formation, concepts and claims. The author's research takes into account the well-travelled path by the developed countries in announcing themselves as the global power. The attention is still on globalization which is still defensible against post-modern, post-colonial and complexity theory claims. In current times, the productive research program of world -system analyses appear even more compelling in the face of the current global turmoil created by the nations.

\subsection{Global Power Shifts and Challenges for Global Order by R. Kappel}

The research article deals with power vacuum that has been created since last few decades. This vacuum is developing because Europe and the United States are currently in a phase of decline whereas Asian countries like India, China and South American country like Brazil are claiming international standing to fill in this vacuum. While analysing the growth of these economies several significant changes are observed in terms of global politics and economic power. The first section of the article discusses the decline in the economy of the United States. These countries have their regional power and they have started to influence on global energy, climate, security, trade and development strategies and policies. The author also investigates that despite the strong economic growth of these countries they are somehow unable to eradicate poverty, unequal distribution of income and other social problems. The second section of the article focuses on the rise of new emerging countries as well as the power blocs like BRIC, ASEAN and others. The third section of the article further tries to find out how the new powers act globally and influence the global economy as well as the global politics. The article also discusses the role of power blocs like the BRICS, ASEAN and IBSA in creating new powers and emergence of global powers. On a concluding note the article suggests that currently the west is not solving all the global problems that are prevailing which are weakening their position and strengthening the position of the emerging powers.

\section{Introduction}

This paper talks about how the Asian economies have developed over the past decades which can lead to a power shift from western country to Asian countries. The Asian countries have seen constant growth in its GDP and annual growth rate whereas the western countries are already developed and have a lower growth rate. Due to the difference in the growth rate many economists have predicted that the future may see the downfall of the western empire as a result of rising Asian empire. The western world is going backwards to the isolation stage which can be observed by the recent event like BREXIT. The paper also talks about the Asian power blocs who are predicted to be leading in the coming years. Asia's rapid economic growth started since the 1960s which can be explained in an international comparative context. In $21^{\text {st }}$ century, Asia is a major developmental success story, having quickly closed the development gap between the region and the rest of the world. Asia's rapid economic growth is the result of a unique model of economic development ${ }^{[1]}$. The main focus is on four key reasons which can lead Asian countries to be powerful enough to make a difference in the world. These reasons are: substantial potential for catching up, favourable geographical characteristics, demographic transition and economic policies and strategies. The second part of the paper focuses on the possibility of a power shift. The paper mainly focuses on China and India as the emerging Asian economies and the United States and European Union as the western countries going through a decline in their economic power and global influence.

\section{Substantial Potential}

The rise of India and China has a profound effect on the economies of developed as well as developing countries. With detailed analyses of these two economies and their economic trends we can convincingly suggest that the rise of China and India as $21^{\text {st }}$ century global powers can be as beneficial to the world as was the rise of the United States in the early $20^{\text {th }}$ century. China and India have a major impact in the global market. Currently, these two countries are the key players in the world economy and changing the face of Asia, while transforming the trade and commerce in the rest of world. Both India and China are becoming globally integrated economies through economic reforms and government incentives. Although China's economic integration with the world has been through trade similar to that of Japan and South Korea, India's global integration is more likely to be through large acquisitions of many industries of advanced economies. It is also inevitable that as China and India march toward becoming global economic powers through trade and investments, their cultural and political influence will also rise. The hegemony of the west has been unchallenged for five centuries. Firstly, the economic powers continues to shift from governments to free markets, at the very time that China and India are beginning to tap the potential of the largest economy due to large domestic markets. Secondly, China and India are those developing nations who are experiencing the world's fastest rates of economic growth. In the massive shifts of geopolitical power in the $21^{\text {st }}$ century there is an ongoing struggle for resources and control over maritime trade routes. And the most powerfully explosive conflict will originate from the powerful superpowers. There is a fierce rivalry between 
powerful nations and emerging political blocks in the pursuit of maintaining and growing their economic prosperity through trade. Asia has confronted major powers, from demographic growth, to the quest for resources, to the establishment of effective communication lines among the countries. India and China's rich resource base matched with its huge populations give potential for resource and economic synergies to the nations. These countries have established their own impressive economic and political influence geopolitically. These advantages have encouraged both the nations to become more open to international markets and they are taking a foothold on the world stage and building influence in the world economic system. These developments lead to a new world order.

\section{Demographic Transition}

The demographic transition is a change from high to low rates of mortality and fertility which has been more dramatic in Asia during the twentieth century than in any other region or historical period. Asia has a large amount of population which comes under the working age population. When a relatively young population reaches working age, one can exploit opportunities for growth. This young population has been a major source of growth for Asia. Higher the number of working age population higher the requirement of employment opportunities which leads to rise in creation of industries to satisfy the demand of people which boosts the economic growth. The miracle occurred in part because South Asia's demographic transition resulted in its working-age population growing at a much faster rate than its dependent population during 1965-90, thereby expanding the per capita productive capacity of South Asian economies. Changes in the age structure of the population created potential for faster economic growth. The working age of the population is a crucial indicator of a region's potential growth. In 2012, India and China had the youngest population in terms of size with the number of people aged below 30 at 704 million and 497 million respectively ${ }^{[2]}$.

Table 1. Labour Supply.

\begin{tabular}{|c|c|}
\hline Nations & Labour Supply (in millions) \\
\hline China & 618 \\
\hline India & 490 \\
\hline European Union & 120 \\
\hline United States & 104 \\
\hline
\end{tabular}

The table shows that both India and China have a huge amount of labour supply. It is dramatic to consider the labour supply of these nations. The figure shows how many people can be employed and could add to the national income as well as national consumption. Asiatic figures dwarf the figures of the US and the EU. The staggering figure of India and China amounting to over 1.1 billion could be a problem for the future of the American and European empires. When the population is more, the number of people who can consume goods and services is also more which causes the economy to experience economic growth. When the economy grows, it results in new industries that can provide more employment to the citizens. A larger population also encourages the nation as well as its citizens to find new technologies to keep the large number of population satisfied.

\section{Geographical Benefits}

The geographical and structural characteristics are by and large favourable. The structural drivers of the economic growth in the Asian region are ongoing trends, feeding expectations that the region's growth will continue for the foreseeable future. Geographical location plays a major part in access to markets. All the great empires have been based around the trade routes which are mostly the sea route. Many of the world's poorest countries are severely hindered because they are landlocked. India dominates the South Asian sub-continent, near important Indian Ocean trade routes. Also the country doesn't have to transport goods and services by land. China has three of the world's busiest ports with which it can raise money through tolls and shipping services as well ${ }^{[3]}$. The landforms of a particular area show the nature and size of commerce that a local can support. For example, a city located in high peaks of Mt. Everest is unable to support constant trade, but on the other hand due to India's Mumbai port on the Arabian Sea, India has been able to flourish economically because they avail trade.

\section{Economically Powerful}

The GDP of both the countries have been seen rising constantly giving the countries a larger economic.

The Asian economies promoted exports through a combination of policies like relatively free trade, incentives on foreign direct investments and macro-economic stability ${ }^{[4]}$. 
Table 2. India and China's GDP and Growth rate

\begin{tabular}{|c|c|c|c|c|}
\hline & \multicolumn{2}{|c|}{ INDIA } & \multicolumn{2}{c|}{ CHINA } \\
\hline YEAR & $\begin{array}{c}\text { AMOUNT } \\
\text { IN USD) }\end{array}$ & GDP GROWTH RATE & AMOUNT (IN USD) & GDP GROWTH RATE (IN \%) \\
\hline 1960 & $\$ 36.536$ billion & $3.7 \%$ & $\$ 59.716$ billion & $-27.3 \%$ \\
\hline 1965 & $\$ 58.76$ billion & $-2.6 \%$ & $\$ 70.436$ billion & $17 \%$ \\
\hline 1970 & $\$ 61.59$ billion & $5.2 \%$ & $\$ 92.603$ billion & $8.7 \%$ \\
\hline 1975 & $\$ 97.159$ billion & $9.1 \%$ & $\$ 163.432$ billion & $7.8 \%$ \\
\hline 1980 & $\$ 183.84$ billion & $6.7 \%$ & $\$ 309.488$ billion & $13.4 \%$ \\
\hline 1985 & $\$ 229.41$ billion & $5.3 \%$ & $\$ 360.858$ billion & $3.9 \%$ \\
\hline 1990 & $\$ 316.697$ billion & $5.5 \%$ & $\$ 1.211$ trillion & $10.9 \%$ \\
\hline 1995 & $\$ 355.476$ billion & $7.6 \%$ & $\$ 2.286$ trillion & $8.5 \%$ \\
\hline 2000 & $\$ 462.147$ billion & $3.8 \%$ & $\$ 6.101$ trillion & $11.4 \%$ \\
\hline 2005 & $\$ 808.901$ billion & $9.3 \%$ & $\$ 11.065$ trillion & $10.6 \%$ \\
\hline 2010 & $\$ 1.657$ trillion & $10.3 \%$ & $8.0 \%$ & $6.9 \%$ \\
\hline 2015 & $\$ 2.09$ trillion & & $\$ 140$ billion & \\
\hline
\end{tabular}

Source: https://data.worldbank.org/country/china and https://data.worldbank.org/country/india

\section{Possibility of a Power Shift}

Global power shifts are strategically and politically significant and it restructures the existing international world power system. The rising economies, military power, political and financial structures of Asian countries show that there might be a global power shift towards Asia. Currently, the world is dominated by the United States and Europe. If we give a look towards the history, Asia has been dominated by the European colonisation for a very long period of time and thereafter dominated by the United States. But today, Asia's economic strength has largely contributed to the world GDP. As seen in the below graph Asian countries contribute more than Europe and the United States. In short, a new global economic order is now emerging to the one that has existed since the World War II. The emerging economies are challenging the four pillars that the U.S.A has led as becoming a power. Those are: it rose rapidly after the World War, trade networks that it had created overtime, dollar's status as a global reserve currency and influence over multilateral institutions. However, Asian economies have formed their own multilateral institutions and have been rapidly growing its economic power as well as trade networks amongst each other. China has surpassed U.S.A and stands as the country with largest purchasing power today ${ }^{[5]}$. When we talk about a country being a superpower it includes economic, political and military power of one particular country like the United States currently. Undoubtedly, the United States is indeed the most powerful country on the world map; however, the $21^{\text {st }}$ century has witnessed changes on the geopolitical front. In this coming scenario, the United States is finding itself in a very difficult position to control and influence the areas which are of utmost global importance in the $21^{\text {st }}$ century.

Asia's role in world economy has completely increased. It can boast two of the BRICs- China and India and gives major investment opportunities in the world market. The continued growth of Asian economic, political and military strengths have contributed to the emergence of Asia's leading countries which are China, Japan and India. Also, Southeast Asia is one of the fastest growing regions of the world and its regional organization which is Association of Southeast Asian Nations (ASEAN) also plays major role in the world economy.

The most influential change that is taking place in the world economy is that USA is losing its power of being the sole influential country in terms of its exclusive position as the world's reserve currency. For the next few decades, no single country will be able to dominate the balance of payments as the United States has done for more than 70 years. USA being the current lead in terms of its purchasing power has a serious threat from China. Global economic influence of China is rapidly increasing and is securing its place as the largest economy for its purchasing power and the labour that they provide. But looking to the current situations the slowdown of the Chinese economy has created a ripple for itself in the global market. When the world is going on such pace where there is no time for instability China can create a mess for its economic position. But the nature of that stability will not be dictated by one or two major players. It will depend on the quality of economic relationships among leading nations, even those that have different economic systems. A good example of the new type of relationship is the natural resource investments made recently by a few countries. This current shift in global economic power will be different in one important respect from the last major shift, 
in 1944. Then, the baton of global economic influence was passed from the U.K. to the U.S., two countries that shared a similar world view ${ }^{[5]}$. Today, in contrast, we're seeing a much faster rebalancing among disparate economic and political systems, each with a different level of reliance on markets and state direction.

But the nature of that stability will not be dictated by one or two major players. It will depend on the quality of economic relationships among leading nations, even those that have different economic systems. A good example of the new type of relationship is the natural resource investments made recently by a few countries. This current shift in global economic power will be different in one important respect from the last major shift, in 1944. Then, the baton of global economic influence was passed from the U.K. to the U.S., two countries that shared a similar world view ${ }^{[5]}$. Today, in contrast, we're seeing a much faster rebalancing among disparate economic and political systems, each with a different level of reliance on markets and state direction.

India is a vibrant democracy. However, managing the pulls and pressures of multiple, electorally significant pressure groups and regional parties can sometimes be a nightmare for any government. This often dilutes focus on governance and sound policy.

The economic power shift is not just a thought rather holds the idea of emergence of other economies and brings those countries in a powerful position. In the last decade, the global balance of power has changed significantly; a fundamental shift towards a multipolar world has been taking place. An overwhelming and unstoppable dynamism is predominantly shifting towards Asia and generating a significant increase of South-South cooperation. Many governments are turning away from the USA and the EU towards the emerging powers, new centres with global influence, in particular China and India. Asia is a crucial region for the EU and US as an arena for trade, markets, resources, military cooperation.

According to the table 3 the country with the largest population is China with almost 1.4 billion people followed by India with 1.2 billion. These two nations amount to almost 2.6 billion people. The United States has a population of 319 million falling in rank after China, India and EU. And EU has a sizeable population of just over half a billion. The average life expectancy for China and India is 72 years which lags considerably behind Europe and America showing that economic development is not ubiquitous in this vast Asiatic continent yet.

When looking at the GDP (PPP) China is number one with $\$ 17.7$ trillion followed by the EU (\$17.6 trillion) and then the US with $\$ 17.5$ trillion. However, India has less than half this level of GDP. Comparison of GDP figures may be problematic; however, we can see that a cohesive and integrated Asian bloc could be a formidable economic challenge to the hegemony of the US and any objective of the EU to increase its dominance.

The yearly economic growth rates are a measure of the level of vitality of these economies. In China from 2004 to 2012 the annual GDP growth rate has ranged from $14.2 \%$ to $7.8 \%$ with $7.8 \%$ being the figure of $7.14 \%$ in 2012 . GDP growth in China over the last few years has been often hovered over $9 \%$ until recent years. The latest figure of $7.14 \%$ is an indication that the growth rate has begun to fall a little. However, it is important to point out that China has had an improved life expectancy among its population. This average life expectancy has increased over the years to 75.2 years from the 2004 figure of 71 years. This represents significant increase which is no small figure when looking at a country as large as China. This shows that China is working on wellbeing and an improved health care system. India is also developing into a power whose influence and expansion in Asia. In India from 2004 until 2012 the annual GDP growth has ranged from $3.23 \%$ in 2004 to $10.55 \%$ in 2010 . Like China, India has over the years enjoyed steady growth rates and its growth does fluctuate on a year to year basis, it is important to point out that India's GDP continues to grow every year. This is a clear sign of the development of this Asian country as an important world player and as a developing country its sheer population size coupled with its more vibrant foreign policy, is enough to get the attention of the west. Furthermore, the statistics also point to a steady increase in India's life expectancy; which has ranged from 63 years in 2004 to 68 years in 2015. Just like China, that despite having a population of over a billion people, India is also developing a modern health care system which falls in line with its developing power in Asia.

Table 3.

\begin{tabular}{|c|c|c|c|c|c|c|c|c|}
\hline Nation & $\begin{array}{c}\text { Population } \\
\text { (in millions) }\end{array}$ & $\begin{array}{c}\text { Life Expectancy } \\
\text { (in years) }\end{array}$ & $\begin{array}{c}\text { Mean } \\
\text { Schooling } \\
\text { Years }\end{array}$ & $\begin{array}{c}\text { Per Capita } \\
\text { Income } \\
\text { (in USD) }\end{array}$ & HDI & $\begin{array}{c}\text { GDP (PPP) } \\
\text { (in trillion } \\
\text { USD) }\end{array}$ & $\begin{array}{c}\text { Growth } \\
\text { Rate }\end{array}$ & $\begin{array}{c}\text { National } \\
\text { Debt } \\
\text { (\% of GDP) }\end{array}$ \\
\hline China & 1,356 & 75.2 & 13.5 & 13,345 & 0.738 & 17.7 & $6.7 \%$ & $22.4 \%$ \\
\hline India & 1,237 & 68.3 & 11.7 & 5,663 & 0.624 & 7.3 & $7.1 \%$ & $51.3 \%$ \\
\hline US & 319 & 79.6 & 16.3 & 53,245 & 0.920 & 17.6 & $1.6 \%$ & $71.2 \%$ \\
\hline EU & 512 & 80 & 15.2 & 34,400 & 0.838 & 17.5 & $1.9 \%$ & $87.4 \%$ \\
\hline
\end{tabular}

Source: World bank reports 
The National debt of India and China is lower compared to the European Union and United States. Comparing the national debt with the nineteen nations of Eurozone, which have a higher average national debt; we can see that the average national debt of India and China is lower. The national debt of United States and European Union is $71.4 \%$ and $87.4 \%$ of GDP respectively whereas on the other hand the national debt of India and China is $51 \%$ and $22 \%$ of GDP respectively. The United States and European Union also have a negative current account balance. However, the EU has relatively small negative current account balance, but the massive current account deficit of the US, amounts to $\$ 386$ billion.

In the last decade, the global balance of power has changed significantly; a fundamental shift towards a multipolar world has been taking place. Many governments are turning away from the USA and the EU towards the emerging powers, new centres with global influence, in particular China and India. It is estimated that by 2050, India's share of the world GDP, will have risen from 6 percent to 13 percent, making it the second largest economy in the world after China.

In its annual "Asian Development Outlook for 2015," published in March of the same year, the Asian Development Bank (ADB) said China's economy is slowing, but Asia will remain a growth hot spot as India and Southeast Asia economies roar ahead. Emerging Asian economies will grow 6.3 percent in 2015 and 2016, unchanged from 2014, the ADB said. According to a May 2014 report by the consulting firm McKinsey \& Company, if ASEAN were a single country, it would already be the seventh-largest economy in the world, with a combined gross domestic product (GDP) of U.S. \$2.4 trillion in 2013. It is projected to rank as the fourth-largest economy by 2050. The competition within is immense. While Indonesia is the largest economy of Southeast Asia, there is no guarantee it will remain so.

\section{Conclusions}

From the above analysis we can say that the world is going to see a power shift from the west world to the Asian region. The economies of the Asian countries are rising at an increasing pace and resulting into creating less influence just by one region and shifting to a multipolar power system. The Asian countries are rising economically as well as politically creating their own position in the global economic market and influencing the world. Asia, being the region with all these combined benefits can largely influence the world economy. Today, we are seeing a much faster rebalancing among disparate economic and political systems, each with a different level of state direction. Global economic influence of Asian countries is rising very fast due to which it becomes clearer that Asian countries are succeeding at creating a major position at a global level. China and India would emerge as economic powers because they have a large, cheap and skilled labour force which will increase their productivity and help in influencing the global markets due to their high GDP as well as high growth rate. With the pace at which China and India are growing, by 2050 China and India will surpass the European Union and United States but only in terms of GDP. China and India still have a long path to travel to surpass European Union and United States in terms of HDI i.e. life expectancy, schooling years as well as per capita income. As discussed before the boom in China and India has been built on foreign investments, and foreign investment favours an environment that promises long-term stability. The pro-market reforms have brought these two nations a long way over the last few decades. India and China are reshaping the world economy gradually. The expectations of the hundreds of millions of their people will only be satisfied if the economies of these countries continue to grow at rates that guarantee jobs for the tens of millions entering the workforce annually. That is a huge responsibility and for a world that depends on the goods and services from those countries, any setback in the two countries would have a huge and possibly disastrous effect. However, with more development come more employment opportunities which results in reduced poverty and higher standard of living. According to $\mathrm{PwC}$, the largest economies in the world are projected to be emerging economies in 2050 led by China (1st), India (2nd) and the US could be down to third place in the global GDP rankings while the EU27's share of world GDP could fall below $10 \%$ by 2050 . The global economic power shift is tending to happen sooner or later. It is yet to be seen whether the projection of 2050 is true or not.

Foreign direct investments have played an important role in the economic development of ASEAN states, especially after the 1990 's. However, the two economic crises, from 1997 and 2007, have significantly influenced the investments' inflows in South-East Asia, each country from the region experiencing a different evolution of the FDI. The purposes of the present paper are to analyse the trends of the ASEAN's inward FDI between 1990 and present, by identifying the factors that have encouraged or discouraged these flows in the context of the two crises, and to estimate the possible future evolution of these investments. In order to achieve these purposes, we have analysed and interpreted information included in several statistical reports, data-bases and year-books. The conclusions underline that, despite the economic downturns, South-East Asia will continue to attract the investors due to its competitive advantages. Foreign direct investments have played an important role in the economic development of ASEAN states, especially after the 1990's. However, the two economic crises, from 1997 and 2007, have significantly influenced the investments' inflows in 
South-East Asia, each country from the region experiencing a different evolution of the FDI. The purposes of the present paper are to analyse the trends of the ASEAN's inward FDI between 1990 and present, by identifying the factors that have encouraged or discouraged these flows in the context of the two crises, and to estimate the possible future evolution of these investments. In order to achieve these purposes, we have analysed and interpreted information included in several statistical reports, data-bases and year-books. The conclusions underline that, despite the economic downturns, South-East Asia will continue to attract the investors due to its competitive advantages. Foreign direct investments have played an important role in the economic development of ASEAN states, especially after the 1990's. However, the two economic crises, from 1997 and 2007, have significantly influenced the investments' inflows in South-East Asia, each country from the region experiencing a different evolution of the FDI. The purposes of the present paper are to analyse the trends of the ASEAN's inward FDI between 1990 and present, by identifying the factors that have encouraged or discouraged these flows in the context of the two crises, and to estimate the possible future evolution of these investments. In order to achieve these purposes, we have analysed and interpreted information included in several statistical reports, data-bases and year-books. The conclusions underline that, despite the economic downturns, South-East Asia will continue to attract the investors due to its competitive advantages.

Foreign direct investments have played an important role in the economic development of ASEAN states, especially after the 1990's. However, the two economic crises, from 1997 and 2007, have significantly influenced the investments' inflows in South-East Asia, each country from the region experiencing a different evolution of the FDI. The purposes of the present paper are to analyse the trends of the ASEAN's inward FDI between 1990 and present, by identifying the factors that have encouraged or discouraged these flows in the context of the two crises, and to estimate the possible future evolution of these investments. In order to achieve these purposes, we have analysed and interpreted information included in several statistical reports, data-bases and year-books. The conclusions underline that, despite the economic downturns, South-East Asia will continue to attract the investors due to its competitive advantages. Foreign direct investments have played an important role in the economic development of ASEAN states, especially after the 1990's. However, the two economic crises, from 1997 and 2007, have significantly influenced the investments' inflows in South-East Asia, each country from the region experiencing a different evolution of the FDI. The purposes of the present paper are to analyse the trends of the ASEAN's inward FDI between 1990 and present, by identifying the factors that have encouraged or discouraged these flows in the context of the two crises, and to estimate the possible future evolution of these investments. In order to achieve these purposes, we have analysed and interpreted information included in several statistical reports, data-bases and year-books. The conclusions underline that, despite the economic downturns, South-East Asia will continue to attract the investors due to its competitive advantages. Foreign direct investments have played an important role in the economic development of ASEAN states, especially after the 1990's. However, the two economic crises, from 1997 and 2007, have significantly influenced the investments' inflows in South-East Asia, each country from the region experiencing a different evolution of the FDI. The purposes of the present paper are to analyse the trends of the ASEAN's inward FDI between 1990 and present, by identifying the factors that have encouraged or discouraged these flows in the context of the two crises, and to estimate the possible future evolution of these investments. In order to achieve these purposes, we have analysed and interpreted information included in several statistical reports, data-bases and year-books. The conclusions underline that, despite the economic downturns, South-East Asia will continue to attract the investors due to its competitive advantages. Foreign direct investments have played an important role in the economic development of ASEAN states, especially after the 1990's. However, the two economic crises, from 1997 and 2007, have significantly influenced the investments' inflows in South-East Asia, each country from the region experiencing a different evolution of the FDI. The purposes of the present paper are to analyse the trends of the ASEAN's inward FDI between 1990 and present, by identifying the factors that have encouraged or discouraged these flows in the context of the two crises, and to estimate the possible future evolution of these investments. In order to achieve these purposes, we have analysed and interpreted information included in several statistical reports, data-bases and year-books. The conclusions underline that, despite the economic downturns, South-East Asia will continue to attract the investors due to its competitive advantages. Foreign direct investments have played an important role in the economic development of ASEAN states, especially after the 1990's. However, the two economic crises, from 1997 and 2007, have significantly influenced the investments' inflows in South-East Asia, each country from the region experiencing a different evolution of the FDI. The purposes of the present paper are to analyse the trends of the ASEAN's inward FDI between 1990 and present, by identifying the factors that have encouraged or discouraged these flows in the context of the two crises, and to estimate the possible future evolution of these investments. In order to achieve these purposes, we have analysed and interpreted information included in several statistical reports, data-bases and year-books. The conclusions 
underline that, despite the economic downturns, South-East Asia will continue to attract the investors due to its competitive advantages. Foreign direct investments have played an important role in the economic development of ASEAN states, especially after the 1990's. However, the two economic crises, from 1997 and 2007, have significantly influenced the investments' inflows in South-East Asia, each country from the region experiencing a different evolution of the FDI. The purposes of the present paper are to analyse the trends of the ASEAN's inward FDI between 1990 and present, by identifying the factors that have encouraged or discouraged these flows in the context of the two crises, and to estimate the possible future evolution of these investments. In order to achieve these purposes, we have analysed and interpreted information included in several statistical reports, data-bases and year-books. The conclusions underline that, despite the economic downturns, South-East Asia will continue to attract the investors due to its competitive advantages.

\section{REFERENCES}

[1] The First Murdoch Commission, , Economic Dynamic in the Asian Region ;www.murdoch.edu.au ; [cited 2016 May]; Available from: http://www.murdoch.edu.au/Murdoch-Co mmission/Commissions/First-Murdoch-Commission/OurThemes/Economic-Dynamics-in-the-Asian-Region/

[2] Sarah Boumphrey, , Special Report: The World's Youngest Populations ;www.blog.euromonitor.com ; [cited 2012 February]; Available from: http://blog.euromonitor.com/20 12/02/special-report-the-worlds-youngest-populations.html

[3] Jeremy Williams, , Geographical factors that affect development ;www.makewealthhistory.org ; [cited 2007 July]; Available from: https://makewealthhistory.org/2007/ 07/01/geographical-factors-that-affect-development/

[4] John Lipsky, , Economic Policies and Global Prosperity: Challenges for Asia and the IMF ;www.imf.org; [cited 2006 September]; Available from: http://www.imf.org/en/ News/Articles/2015/09/28/04/53/sp090706

[5] Dennis Chesley, Miles Everson, John Garvey, , Global Power Shift ;www.strategy-business.com ; \%5Bcited 2016 April\%5D; Available from: https://www.strategy-business. com/article/Global-Power-Shift\%3Fgko=d56bb 